\title{
DEVELOPING THEORIES OF NON WESTERN PUBLIC ADMINISTRATION THROUGH THE ISLAMIZATION OF PUBLIC ADMINISTRATION
}

\author{
WisberWiryanto \\ Center of Administrative Reform Studies, National Institute of Public Administration \\ wisberwiryanto@yahoo.com
}

Keywords : Islamization of Public Administration; Secularization of education, NonWestern Public Administration.

Abstract-Public Administration is a branch of Social Science disciplines taught at universities in Indonesia. Indonesia is a country that is predominantly Muslim. However, the education system faces problems of secularization of education, that is split between education and religion. This can be seen in the teaching of public administration disciplines which mostly uses Western Public Administration with Western worldview than the Islamic worldview. Therefore, it is necessary to develop the theory of NonWestern Public Administration through the Islamization of Public Administration. The research used library research method. Collecting and analyzing data based on descriptive qualitative method, through textbooks that are relevant for this research. The research will answer a main question: how to developing theories of non-Western Public Administration. The focus of study: the Islamization of Public Administration. The locus of study: some institutions of higher education that have faculties/departments science of Public Administration. This research was conducted in Indonesia in 2018. The results of the study are showed that developing theories of non-Western Public Administration can be done in various ways, among others, by (1) the study Qur'an as a source of knowledge; (2) the vision/mission university an Islamic Perspective; (3) the Islamization of Public Administration; (a) the curriculum/syllabus of Public Administration; and (b) the textbook of Public Administration for higher education in Indonesia.

\section{Introduction}

Public Administration is a branch of Social Science disciplines taught at universities in Indonesia. Indonesia is country that is predominantly Muslim. However, the education system faces problems of secularization that is split between education and religion. This can be seen in the teaching of public administration disciplines which mostly uses Western worldview than the Islamic worldview.

What's the problem with the theory of public administration that is taught in universities comes from secular Western theories. According to Al-Attas, S.M.N. most of science today are basically convinced and interpreted by the West and therefore strongly influenced the West in the eyes of the East. The dominant characteristic way of life and the spirit of the West is based on four pillars: secularism, humanism, dualism and tragedy. The secularization of knowledge that is causing serious problems if not resolved (Daud, WMNW, 2013).

The same phenomenon elsewhere, especially in discussions within the government. Discussions of public administration to achieve the goals discussed only with Western theories emptying the science of values revelation. But, the results did not achieve the expected goodness for the safety of life in this world and hereafter. Because, discourse never discussed theories of 
public administration in the perspective of Islam derived from the Qur'an and the Hadith of the Prophet.

This situation indicates missing a chain of Islamic public administration from the series chain of the public administration science. The series of public administration science only consists of a chain of Western theories. Therefore, it is necessary to connect a chain of unbroken chain of public administration that is the perspective of Islam (Islamic Public Administration) which is the theory derived from the Qur'an as a source of knowledge; into a series of chain science of public administration so that it becomes a chain the of unified science of public administration.

As a problem solving the secularization of knowledge, among Islamic intellectuals propose the idea of Islamization of knowledge. The idea of Islamization of knowledge can be done through approaches among others instrumentalistic, justification, sacralization, Islamic paradigm, and integration (Handrianto, Budi, 2010). One of the integration approaches was chosen in this study.

Why the Islamization of Knowledge should be chosen? According Al-Attas that modern knowledge is not neutral because it is infused with the cultural and philosophical, reflecting the consciousness and experience of Western man (Daud, WMNM, 1998: 291). Therefore necessary for muslims scholar to Islamize knowledge.

Western science is not neutral, because it is based on Western worldview containing values such as rationalism, materialism, liberalism and secularism. For example, secularism in Western science is known to be a separation between science and religion. While based on Islamic worldview, religion and science are not separate things. In addition, Western epistemology uses only empiricism and rationalism; while Islamic epistemology recognizes four sources of knowledge: sense, reason, intuition and revelation (Husaini,A, 2013: 48). Therefore, as a solve the problem secularization of knowledge it is necessary the Islamization of Knowledge.

The integration approach is used to integrate Western science with Islamic sciences. Ismail Raji al-Faruqi is one of the leaders of Islamization of knowledge. Al-Faruqi (1982) offers 12 steps of Islamization of knowledge. He said, objectives the Islamization of knowledge, for the direction of the flow of Islamic thought to the streets that accomplish the fulfillment of the pattern of God's plan. In line with that goal, according to Al-Attas, focus to manifest good man, who will perform various roles in society (Daud, WMNW, 2013).

What is the relevance of the objectives of the Islamization of knowledge to the objectives of education in Indonesia? Tafsir, Ahmad (2012) explains the purpose of education according to Article 31 UUD-1945 paragraph (3) The Government services and organizes a national education system, which enhances iman, taqwa and noble character in order to educate the nation's life, regulated by law. Furthermore, the Law No. 20/2003 concerning National Education System. Article 3 of the Law states that the objectives of national education for the development of the potential of learners to become human beings who are faithful and devoted to God Almighty are noble, healthy, knowledgeable, capable, creative, independent, and become democratic and responsible citizens. Thus, the objectives of the National education system and the Islamization of knowledge are relevant.

Therefore, to solve the problem caused by secularization of public administration science in Indonesia should be done through Islamic worldview. Based on the background of 
the problem, it is necessary to develop the theory of the Non-Western Public Administration through the Islamization of Public Administration. The research will answer a main question: how to developing theories of Non-Western Public Administration.

\section{Literature Review}

This study was conducted through a review of the literature of research results relevant to the Public Administration an Islamic Perspective. This research is conducted to find out what needs to be done in the framework of development of public administration. From the results of literature review that has been done, can be collected 9 (Nine) articles the International Discourse of Public Administrative an Islamic Perspective 2012-2017. The titles of these articles are in table 1.

Table : 1: The International Discourse of Public Administration an Islamic Perspective 2012-2017

\begin{tabular}{|c|c|c|}
\hline Year & Authors & $\begin{array}{l}\text { Title of Articles: Public Administration an Islamic } \\
\text { Perspectif }\end{array}$ \\
\hline 2012 & $\begin{array}{l}\text { Salleh, Mohammac } \\
\text { Johdi and Mohamad } \\
\text { Nazifah Alwani }\end{array}$ & $\begin{array}{l}\text { Islamic Principles of Administration: Implication on Pracies in } \\
\text { Organization }\end{array}$ \\
\hline \multirow[t]{2}{*}{2013} & \multirow[t]{2}{*}{ Drechsler, Wolfgang } & $\begin{array}{l}\text { Three Paradgms of Governance and Administration: Chinese, } \\
\text { Western and Islamic }\end{array}$ \\
\hline & & $\begin{array}{l}\text { Islamic Public Administration - The Missing Dimension in } \\
\text { NISPAcee (The Network of Institutes and Schools of Public } \\
\text { Administration in Central and Eastern Europe) Research }\end{array}$ \\
\hline \multirow[t]{4}{*}{2014} & Noh, Abdillah & $\begin{array}{l}\text { Islam Public Policy and Public Administration in Malaysia: } \\
\text { Negotiating Complexities }\end{array}$ \\
\hline & Samier, Eugenie A. & $\begin{array}{l}\text { Designing Public Administration Curriculum for the United } \\
\text { Arab Emirates: Principles for Graduate Programmes for a } \\
\text { Modernising Arab Islamic State }\end{array}$ \\
\hline & Urinboyev, Rustamjon & $\begin{array}{l}\text { Is there an Islamic Public Administration Legacy in Post-Soviet } \\
\text { Central Asia? An Ethnograpic Study of Everyday Mahalla Life } \\
\text { in Rural Ferghana, Uzbekistan }\end{array}$ \\
\hline & Drechsler, Wolfgang & $\begin{array}{l}\text { What is Islamic Public Administration and why should we } \\
\text { study it in the "Second World"? }\end{array}$ \\
\hline 2015 & Drehsler, Wolfgang & $\begin{array}{l}\text { Islamic PA (Public Administration) - does it exist, what is it, } \\
\text { and why and how should we study it? }\end{array}$ \\
\hline 2016 & Muhammad & $\begin{array}{l}\text { The Administration of Prophet Muhammad (PBUH) and Its } \\
\text { Impact on the Contemporary States }\end{array}$ \\
\hline 2017 & $\bar{W}$ & $\begin{array}{l}\text { The Need of Public Administration: An Islamic Perspective } \\
\text { Higher Education in Indonesia }\end{array}$ \\
\hline
\end{tabular}

Source: See bibliography for more data. 
Based on the title of the articles, it is known that the research entitled developing theories of non-Western Public Administration through the Islamization of Public Administration, has not been done. Therefore, it is deemed necessary to conduct research on developing theories of Non Western Public Administration through the Islamization of Public Administration.

Al-Faruqi (1982) arranging the Islamization of knowledge theory include obyectives (5), steps (12), consist of: (1) Mastery of the modern discipline: categories breakdown; (2) Discipline survey; (3) Mastery of the Islamic Legacy: the anthology; (4) Mastery of the Islamic Legacy: the analysis; (5) Establisment of the specific relevance of Islam to the disciplines; (6) Critical assesmen of the modern discipline; (7) Critical assessment of the legacy; (8) Survey of the Ummah's major problems; (9) Survey of the problems humankind; (10) Creative analysis and syntheses; (11) Recasting the disciplines under the framework of Islam. The university textbook; (12) Dissemination of Islamization of Knowledge.

\section{Methods}

The research used library research method. Collecting and analyzing data based on descriptive qualitative method, through secondary data from websites and books that are relevant to developing theories of non-Western public administration through the Islamization of public administration. The research will answer a main question: how to developing theories of Non-Western Public Administration. The focus of study: developing theories of non-Western Public Administration through the Islamization of Public Administration. The locus of study: Some Islamic higher education institutions that have the public administration science faculty/program. With purposive sampling technique obtained 17 institutions of Islamic higher education in Indonesia who have a department of public administration sciences. This research was conducted in Indonesia in 2018.

\section{Result and Discussion}

Developing theories of non western public administration through the Islamization of public administration in higher education is a necessity. The results of the literature research indicate that developing theories of non-Western public administration theory can be done in various ways, among others by Al-Qur'an source of knowledge; arranging the vision/mission of university an Islamic Perspective; the Islamization of public administration, among others preparing the curriculum/syllabus of Public Administration; and writing the Public Administration textbook an Islamic perspective for higher education in Indonesia.

\section{First, the Study Al-Qur'an as a source of knowledge}

Rahman, Afzalur (1981) in the book "Quranic Science" states, this effort is intended to introduce to Muslims, about science and knowledge that comes from al-Qur'an, which has an enormous influence on the education and culture of the people human. The effect can be seen among others from scientific discoveries and the growth of science very rapidly in the world of Islam in the 7th century to the 14th century-M. Rahman in his research revealed the discipline of science that comes from al-Qur'an as much as 27 branches of science. Furthermore, Hude, M.D., Basri, H., M. Abbas, and Al-Hafiz, M.A (2002), in a study with a procedure or system of scientific work, reveals science in the perspective of the Qur'an as much as 30 branches of science.

Based on the results of these two studies, can be compiled knowledge in the perspective of al-Qur-an a number of 40 branches. The branches of science that requires the development of 
the Islamic perspective for universities. The branches of science includes scientific group, the Natural Science; Social Science; and Humanity Sciences of a body of knowledge. Therefore, from this study it is known that administrative science (Hude et al., 2002) is one of 40 branches of science in the Qur'an Perspective.

Thus, through the study of the Qur'an as the source of knowledge it can be done developing theories of non-Western public administration to produce theories of public administration an Islamic perspective.

\section{Second, the vision/mission of university in Indonesia an Islamic perspective}

A vision statement or simply a vision, is a public declaration that schools or other educational organizations use to describe their high-level goals for the future - what they hope to achieve if they successfully fulfill their organizational purpose or mission. A vision statement may describe a school's loftiest ideals, its core organizational values, its long-term objectives, or what it hopes its students will learn or be capable of doing after graduating. (The Glossary of Education Reform, 2015).

This research collects the vision/ mission of universities in Indonesia, especially those that have faculty / field of public administration study. The collected vision expressed in Islamic perspective is as follows (table 2).

Table 2: The Vision/Mission of University in Indonesia an Islamic Perspective

\begin{tabular}{|l|l|l|}
\hline University & Vision/Mission & Faculty/Program \\
\hline $\begin{array}{l}\text { 1. Universitas 'Aisyiyah } \\
\text { Yogyakarta }\end{array}$ & $\begin{array}{l}\text { University based on Islamic value } \\
\text { making Progress }\end{array}$ & $\begin{array}{l}\text { Public } \\
\text { Administration }\end{array}$ \\
\hline $\begin{array}{l}\text { 2.Universitas Darussalam } \\
\text { Ambon }\end{array}$ & $\begin{array}{l}\text { University based on Islamic values } \\
\text { 3.Universitas Ibnu Chaldun } \\
\text { Jakarta }\end{array}$ & $\begin{array}{l}\text { Implementing an Islamic nuance } \\
\text { Administration }\end{array}$ \\
\hline $\begin{array}{l}\text { 4.Universitas Islam Jember } \\
\text { curriculum }\end{array}$ & $\begin{array}{l}\text { University based on Ahlussunnah Wal } \\
\text { Jamaah An-Nahdliyah }\end{array}$ & $\begin{array}{l}\text { Public } \\
\text { Administration }\end{array}$ \\
\hline $\begin{array}{l}\text { 5. Universitas Islam } \\
\text { Kalimantan Banjarmasin }\end{array}$ & $\begin{array}{l}\text { University based on the development of } \\
\text { science, technology, art and science of } \\
\text { Islam }\end{array}$ & $\begin{array}{l}\text { Public } \\
\text { Administration }\end{array}$ \\
\hline $\begin{array}{l}\text { 6. Universitas Islam Malang } \\
\text { Aniversity based on akhlaqul karimah, } \\
\text { based on Islam Ahlussunnah } \\
\text { waljama'ah }\end{array}$ & $\begin{array}{l}\text { Public } \\
\text { Administration }\end{array}$ \\
\hline $\begin{array}{l}\text { 7. Universitas Islam Negeri ar- } \\
\text { Raniry Banda Aceh }\end{array}$ & $\begin{array}{l}\text { University of development and } \\
\text { integration of Islamic science, science, } \\
\text { technology and art }\end{array}$ & $\begin{array}{l}\text { Public } \\
\text { Administration }\end{array}$ \\
\hline $\begin{array}{l}\text { Sultan Syarif Kasim Riau } \\
\text { Universitas Islam Negeri }\end{array}$ & $\begin{array}{l}\text { University that development the } \\
\text { art integral }\end{array}$ & $\begin{array}{l}\text { Public } \\
\text { Administration }\end{array}$ \\
\hline
\end{tabular}




\begin{tabular}{|c|c|c|}
\hline $\begin{array}{l}\text { 9. Universitas Islam Negeri } \\
\text { Sunan Gunung Jati Bandung }\end{array}$ & $\begin{array}{l}\text { University based revelation guides } \\
\text { science in the frame of morality } \\
\text { karimah }\end{array}$ & $\begin{array}{l}\text { Public } \\
\text { Administration }\end{array}$ \\
\hline 10.Universitas Islam Riau & $\begin{array}{l}\text { Organizing Islamic da'wah } \\
\text { Integrating of Islam and science }\end{array}$ & $\begin{array}{l}\text { Public } \\
\text { Administration }\end{array}$ \\
\hline $\begin{array}{l}\text { 11. Universitas Islam Syekh } \\
\text { Yusuf Tangerrang }\end{array}$ & $\begin{array}{l}\text { University based on aqidah, shari'a and } \\
\text { akhlaqul karimah based on al-Qur'an } \\
\text { and as-sunnah }\end{array}$ & $\begin{array}{l}\text { Public } \\
\text { Administration }\end{array}$ \\
\hline $\begin{array}{l}\text { 12. Universitas Islam “45” } \\
\text { Bekasi }\end{array}$ & $\begin{array}{l}\text { Cultured the value of aqidah that guided } \\
\text { by Al-Qur'an and Al-Sunnah }\end{array}$ & $\begin{array}{l}\text { Public } \\
\text { Administration }\end{array}$ \\
\hline $\begin{array}{l}\text { 13.Universitas Malikussaleh } \\
\text { Lhokseumawe }\end{array}$ & $\begin{array}{l}\text { University based on the value of local } \\
\text { wisdom and Islamic Shari'a }\end{array}$ & $\begin{array}{l}\text { Public } \\
\text { Administration }\end{array}$ \\
\hline $\begin{array}{l}\text { 14. Universitas Mohammad } \\
\text { Natsir Bukittinggi }\end{array}$ & $\begin{array}{l}\text { Islamic University that excellent to } \\
\text { produce insan kamil }\end{array}$ & $\begin{array}{l}\text { Public } \\
\text { Administration }\end{array}$ \\
\hline $\begin{array}{l}\text { 15. Universitas Muhammadiyah } \\
\text { Jakarta }\end{array}$ & $\begin{array}{l}\text { University based on the value of al- } \\
\text { Islam and Muhammadiyah }\end{array}$ & $\begin{array}{l}\text { Public } \\
\text { Administration }\end{array}$ \\
\hline $\begin{array}{l}16 . \\
\text { Muhammadiyah }\end{array}$ & $\begin{array}{l}\text { Organizing the educational process to } \\
\text { improve iman and taqwa }\end{array}$ & $\begin{array}{l}\text { Public } \\
\text { Administration }\end{array}$ \\
\hline $\begin{array}{l}\text { 17. Universitas Sultan Fata } \\
\text { Demak }\end{array}$ & University-based iman and taqwa & $\begin{array}{l}\text { Public } \\
\text { Administration }\end{array}$ \\
\hline
\end{tabular}

Source: See bibliography for more data.

Thus, it is known there are 17 universities that have public administration study programs that have a vision/mission in the perspective of Islam. However, the vision /mission has not been cascaded into the curriculum/syllabus. Therefore, in developing theories of non-Western public administration through the Islamization of public administration on their curriculum/syllabus, it is necessary to cascade the vision/mission related activities through the Islamization of knowledge into the curriculum/syllabus of the department of public administration an Islamic perspective was further developed by the university concerned.

\section{Third, The Islamization of Public Administration}

Al-Faruqi's theory: The 12 steps of the Islamization of Knowledge (IOK) are implemented to achieve 5 goals. This theory is used to conduct IOK disciplines of contemporary science which contains Western-secular elements but is empty of religious elements, resulting in a textbook of the Islamization of Public Administration (IOPA) which contains elements of science and religion with the approach of Islamic worldview.

Table 3: The Islamization of Public Administration: Objectives, Steps and Outputs

\begin{tabular}{lll}
\hline \multicolumn{2}{c}{ Objectives and Steps } & $\begin{array}{l}\text { Expected } \\
\text { Outputs }\end{array}$ \\
\hline The IOK & The IOPA & $(3)$ \\
\hline$(1)$ & $(2)$ & \\
\hline First: To master the modern disciplines & \\
\hline
\end{tabular}




\begin{tabular}{|c|c|}
\hline $\begin{array}{l}\text { 1. Mastery of the modern } \\
\text { discipline:categories } \\
\text { breakdown }\end{array}$ & $\begin{array}{l}\text { 1. Mastery of the Western Public- A list of } \\
\text { Administration (PA): } \\
\text { - Study both categories; }\end{array}$ \\
\hline 2. Discipline survey & $\begin{array}{ll}\text { PA; } & \text { of Wester } \\
\text { - What are the categories and the theories } & \text { PA. } \\
\text { of Western PA? } & \end{array}$ \\
\hline \multicolumn{2}{|c|}{ Second: To master the Islamic legacy } \\
\hline $\begin{array}{l}\text { 3. Mastery of the Islamic- } \\
\text { legacy: } \\
\text { the anthology }\end{array}$ & $\begin{array}{l}\text { 2. Mastery of the Islamic-Legacy of PA: - A list of } \\
\text { - Study of the anthology Islamic-legacy of categories; } \\
\text { PA; }\end{array}$ \\
\hline $\begin{array}{l}\text { 4. Mastery of the Islamic- } \\
\text { legacy: } \\
\text { the analysis }\end{array}$ & $\begin{array}{l}\text { - What are the categories and the theories - Analysis stud } \\
\text { of the } \\
\text { Islamic-legacy of PA? }\end{array}$ \\
\hline \multicolumn{2}{|c|}{ Third: To establish the specific relevance of Islam to each area of modern knowledge } \\
\hline $\begin{array}{l}\text { 5. Establishment of the specifi } \\
\text { relevance of Islam to the } \\
\text { disciplines }\end{array}$ & $\begin{array}{l}\text { 3. Determination of relevance of the Western \&Determining } \\
\text { Islamic-legacy of PA: the relevance } \\
\text { - Determining the relevance of the Wester of Western \& } \\
\text { \& Islamic legacy PA; Islamic-legacy } \\
\text { - What is the relevance of Western \&Islami of PA } \\
\text { PA? }\end{array}$ \\
\hline $\begin{array}{l}\text { 6. Critical assessment of the } \\
\text { modern discipline }\end{array}$ & $\begin{array}{l}\text { 4. Assessment of the critical differenc Assessment of } \\
\text { Western \& } \\
\text { Islamic-legacy of PA: }\end{array}$ \\
\hline $\begin{array}{l}\text { 7. Critical assessment of the } \\
\text { legacy }\end{array}$ & $\begin{array}{l}\text { - Assess the difference in Western \& Western \& } \\
\text { Islamic PA; } \\
\text { - What are the differences Western \& } \\
\text { Islamic PA? }\end{array}$ \\
\hline $\begin{array}{l}\text { 8. Survey of the } \mathrm{Ur} \\
\text { major }\end{array}$ & $\begin{array}{l}\text { 5. Study the problems of Muslims/huma The map of } \\
\text { related } \\
\text { P PA Issues }\end{array}$ \\
\hline Problems & $\begin{array}{l}\text { - Studies issuesMuslims and huma } \\
\text { related PA; }\end{array}$ \\
\hline $\begin{array}{l}\text { 9. Survey of the proble } \\
\text { humankind }\end{array}$ & - What is the problem related to PA? \\
\hline
\end{tabular}

Fourth: Creative synthesis between the legacy and modern knowledge

10. Creative analysis and syntheses
6. To study the synthesis of Western and Islam The study of legacy of synthesis

- Make a synthesis of Western \& Islamic Wes- tern

- How to synthesis of Western \& Islamic PA and Islamic legacy of PA

\section{Fifth: To launch Islamic Though to the fulfillment on the divine pattern of Allah SWT}

11. Recasting the disciplines 7. Arranging and disseminating Islamic PA The Islamic under textbook;

PA textbook 


\begin{tabular}{cll}
\hline \multicolumn{1}{c}{ the framework of Islam: } & $\begin{array}{l}\text { - Arranging and disseminating PA } \\
\text { textbook; }\end{array}$ & $\begin{array}{l}\text { contains } \\
\text { analysis \& }\end{array}$ \\
university textbook & - How to arrange and disseminate Islamic & \\
& PA & \\
\hline 12. Dissemination of IOK & textbook? & synthesis \\
\hline
\end{tabular}

Source: Al-Faruqi, Ismail (1982), Islamization of Knowledge: General Principles and Workplan. Maryland: International Institute of Islamic Thought, Pp. 38-46 (data processed).

Developing theories of non-Western Public Administration through IOPA, referring to the IOK stage (table 3, column 1) consisting of 12 steps. Furthermore, the IOK stage developed into the IOPA stage includes 7 steps (table 3, column 2). Stage IOK and IOPA is the step of converting input into output (IOPA textbook), through mechanism process of analysis and synthesis. The IOPA input, process and output stage, as follows:

The IOPA inputs, is an input covering the categories, principles, methodologies, issues and themes of PA Western and Islamic legacy.

The IOPA process, is the IOPA analysis and synthesis mechanism. The steps, as follows:

(1) The analysis of PA Western and PA categories of Islamic treasures, in step 1 (mastery of the Western PA) and step 2 (mastery of Islamic legacy);

(2) Relevance analysis, carried out in step 3 (determining the relevance of Western PA and Islamic legacy);

(3) Differences analysis, done in step 4 (critical assessment-difference of Western PA and Islamic legacy); and

(4) Problem analysis, done in step 5 (study of Islamic \& human problems related to PA).

Second, synthesis mechanism and steps (table 3, column 2, step 5-7), as follows:

(5) The synthesis of Western PA and Islamic legacy, is done in step 6 (synthesizing Western PA \& Islamic legacy). Synthesis is done through the process of dialectics and multiple processes, as follows:

(a) The dialectical process places the results of the PA analysis as a thesis; while the results of analysis of Islamic treasures as anti thesis PA; then synthesis of both; and

(b) The dual process in question is the theory of IOK Al-Attas using the Islamic worldview glasses. This process is done by isolating and removing un-Islamic things from Western elements and concepts; then embed Islamic elements and concepts into new and foreign elements and concepts. Instead, put Islam within the framework of the secular-liberal Western worldview. Thus the synthesis mechanism in the process of IOK becomes operational and the result is not contrary to the teachings of Islam.

IOPA output, is the result of the final stages of a non-western PA textbook with the Islamic worldview approach called IOPA textbook.

Thus it is known that by doing how to IOK and IOPA: Objectives, Steps and Outputs (table 3) it can be developed theories of non-Western PA to produce theories of the IOPA. PA Theory. Furthermore, the developing theories of non-Western PA through the IOPA steps are poured into the IOPA textbook.

The resulting IOPA textbooks containing the PA categories include Western PA analysis, PA analysis of legacy legislation, and PA synthesis in an Islamic perspective. It is 
hoped that the IOPA textbook will meet the needs of reference of students and lecturers in the learning process of PA in Islamic perspective.

\section{a. The Islamization of Curriculum/syllabus: Public Administration}

Curriculum refers to the means and materials with which students will interact for the purpose of achieving identified educational outcomes (Ebert,Ebert and Bentley, 2013). The college curriculum generally contains subjects and teaching materials sourced from Western. The teaching material was developed based on a Western worldview containing the values of secularism, liberalism and materialism. This is the phenomenon of secularization public administration science at various universities in Indonesia.

The universities in general as already known, have only a vision/mission with an Islamic perspective (table 2). But in general, universities with public administration courses do not have the curriculum/syllabus of Public administration an Islamic Perspective. For example, the curriculum/syllabus for Course Governance and Public Administration in Islam (table 4).

Table 4: Course Governance and Public Administration in Islam

\begin{tabular}{|c|c|c|}
\hline Course Content & Objective & Reading List \\
\hline $\begin{array}{l}\text { Week 1: } \\
\text { The Meaning of and } \\
\text { sources of Islamic } \\
\text { Administration }\end{array}$ & $\begin{array}{l}\text { To define the word } \\
\text { aministration. They should } \\
\text { be able to mention sources } \\
\text { of Islamic administration }\end{array}$ & $\begin{array}{l}\text { Al-Buraey, M.A. (1990) Management and } \\
\text { Administration in Islam, Dhahran..Pp. } \\
\text { 227-234. }\end{array}$ \\
\hline $\begin{array}{l}\text { Week 2: } \\
\text { Qur'anic Teachings } \\
\text { on Governance }\end{array}$ & $\begin{array}{l}\text { To identify some qur'anic } \\
\text { verses that speak on } \\
\text { governance }\end{array}$ & $\begin{array}{l}\text { Adebayo, RI (2010) "Islam, Democracy } \\
\text { and Good Governance"; Orita Ibadan } \\
\text { Journal of Religius Study, vol XLI }\end{array}$ \\
\hline $\begin{array}{l}\text { Week 3: } \\
\text { Islamic System of } \\
\text { Government and } \\
\text { other forms of } \\
\text { Government }\end{array}$ & $\begin{array}{l}\text { To compare and contrast } \\
\text { the Islamic system of } \\
\text { government and other } \\
\text { forms of government }\end{array}$ & $\begin{array}{l}\text { Al-Buraey, M.A. (1990) Management and } \\
\text { Administration in Islam, Dhahran.. Pp. } \\
\text { 49-92 }\end{array}$ \\
\hline $\begin{array}{l}\text { Week 4: Prophetic } \\
\text { Model of } \\
\text { Governance in } \\
\text { Madinah }\end{array}$ & $\begin{array}{l}\text { Tto explain the prophetic } \\
\text { model of governance in } \\
\text { Madinah }\end{array}$ & $\begin{array}{l}\text { Haykal, H (1982) The Life of } \\
\text { Muhammad. North American Trust } \\
\text { Publication. Pp.173-199 }\end{array}$ \\
\hline $\begin{array}{l}\text { Week 5: The } \\
\text { Rightly-Guided } \\
\text { Caliphs and their } \\
\text { method } \\
\text { governance }\end{array}$ & $\begin{array}{l}\text { To describe how each of } \\
\text { the caliphs emerged and } \\
\text { their methods of } \\
\text { governance }\end{array}$ & $\begin{array}{l}\text { Rahim, A (1983) Islamic History. Logos, } \\
\text { Islamic Publication Bureau. Pp. 65-76 }\end{array}$ \\
\hline $\begin{array}{l}\text { Week 6: Qualities } \\
\text { of the 'Ulul-Amr }\end{array}$ & $\begin{array}{l}\text { To mention some qualities } \\
\text { of the 'ulul- Amr }\end{array}$ & $\begin{array}{l}\text { Qardawi, Y. (1988) State in Islam. Cairo, } \\
\text { El-Falah.Pp.210-218. }\end{array}$ \\
\hline $\begin{array}{l}\text { Week 7: } \\
\text { Duties of Muslim } \\
\text { Leader }\end{array}$ & $\begin{array}{l}\text { To identify some of the } \\
\text { duties of a Muslim leader }\end{array}$ & $\begin{array}{l}\text { Syed Ismail al-Qudsy SH \& Abd Rahman, } \\
\text { Asmak (2011) "Efective Governance in } \\
\text { the Era of Calipha Umar Ibn Al-Khatab }\end{array}$ \\
\hline
\end{tabular}


(634-644). European Journal of Social

Science, Vol.18, No. 4.

\begin{tabular}{|c|c|}
\hline $\begin{array}{l}\text { Week 8: } \\
\text { Shura: Its Meaning, } \\
\text { mode and scope }\end{array}$ & $\begin{array}{l}\text { To define the term shura Sharfuddin, IM (1987), Toward an } \\
\text { and make reference to Islamic Administrative Theory". The } \\
\text { some Qur'anic verses American Journal of Islamic Social } \\
\text { which allude to the Science, vol.4, No.2. Pp. 229-244 } \\
\text { concept }\end{array}$ \\
\hline $\begin{array}{l}\text { Week 9: } \\
\text { Detailed Study of } \\
\text { Al-Adl wal-Ihsan }\end{array}$ & $\begin{array}{l}\text { To expose the students to } \\
\begin{array}{l}\text { Abd Rahman, A. (1996) Administrative } \\
\text { the Islamic injuctions }\end{array} \\
\begin{array}{ll}\text { 'adl wal-ihsan } & \text { Thesponsibility: An Islamic Perspective." } \\
& \text { The American Journal of Islamic Social } \\
& \text { Sciences, vol.13, No.4. Pp.497-517. }\end{array}\end{array}$ \\
\hline $\begin{array}{l}\text { Week 10: } \\
\text { Islamic Perspective } \\
\text { on International } \\
\text { Relations }\end{array}$ & $\begin{array}{l}\text { To introduce students to Baderin, MA (200) "The Evolution of } \\
\text { the relationship of the Islamic Law of Nations and the Modern } \\
\text { Muslim world with other International Order"; The American } \\
\text { nation, and how this was Journal of Islamic Social Sciences, vol. } \\
\text { facilitated during the time 17, No.2. Pp.57-80 } \\
\text { of the Prophet and the } \\
\text { Righty Guided caliphs }\end{array}$ \\
\hline $\begin{array}{l}\text { Week 11: Study of } \\
\text { Selected Treaties } \\
\text { during the Prophetic } \\
\text { era }\end{array}$ & $\begin{array}{l}\text { To describe and critically Haykal, MH (1976) The Life of } \\
\text { appraise the contents of Muhammad; North American Trust } \\
\text { some treaties during the Publications. Pp.340-359. } \\
\text { prophetic era }\end{array}$ \\
\hline $\begin{array}{lll}\text { Week 12: } & \text { Class } \\
\text { Test } & & \end{array}$ & \\
\hline
\end{tabular}

Source: Adebayo, Rafiu Ibrahim (n.d.) Course Governance and Public Administration in Islam, Faculty of Arts, University of Ilorin-Nigeria. (data processed).

Therefore, a curriculum/syllabus department of public administration an Islamic perspective should be derived from existing vision/mission through the Islamization of public administration, like the example above.

\section{b. The Islamiztion of Textbook: Public Administration}

Developing theories of non-Western public administration through the Islamization of public administration can also be done by writing the public administration textbook an Islamic perspective for universities in Indonesia

This research can collect 3 (three) public administratition textbooks an Islamic perspective written by Indonesian author. (1) Noer, Deliar (1978) is the author of one book a monumental work of Indonesian scholars in the field of administration of Islam, entitled "Administration of Islam in Indonesia" (English version). Furthermore, to meet the needs of the development of the book administration in the Islamic perspective, this book was translated into Indonesian by Noer, D. (1983) entitled "Administration of Islam in Indonesia" (Indonesian version). (2) Rahim Husni (1998) is sthe author entitled "Administration Authority System in Islam" written by Rahim, Husni. (1998). (3) In addition, Ali, MD., Azhari, T. and Daud H., wrote a book titled "Islam for the disciplines of law and social politics. 
This data shows, public administration textbook in the Islamic perspective very little. Therefore, it is necessary to take the steps of IOPA as mentioned above about how to develop theories of non-Western public administration to produce theories of public administration an Islamic perspective. Furthermore, the result of developing theories of non-Western public administration through IOPA steps is poured into the IOPA textbook. It is hoped that the IOPA textbook will meet the needs of reference of students and lecturers in the learning process of PA in Islamic perspective. Therefore, IOPA textbooks can be produced through the IOK, for use as reference for reading list the curriculum/sylabus department of public administration.

\section{Conclusion}

Developing theories of Non Western Public Administration can be done in various ways, among others, by the study Qur'an as a source of knowledge; the vision/mission university

an Islamic Perspective; the Islamization of Public Administration; includes the curriculum/syllabus of Public Administration; and the textbook of Public Administration for higher education in Indonesia.

As a recommendation, developing theories of non-Western can be implemented in lecturers at universities, and it is an urgent need for solving educational problems caused secularization administration science.

\section{References}

Adebayo, Rafiu Ibrahim (n.d.) Course Governance and Public Administration in Islam, Faculty of Arts, University of Ilorin-Nigeria. Available at: https:www.academia.edu/19755200/RIS-445Governance-and-Public-Administration-In-Islam, accessed on January 8,

Al Attas, Syed Muhammad Naquib, in Daud Wan Mohd Nor Wan Daud (2013), Islamisasi Ilmu-Ilmu Kontemporer dan Peran Universitas Islam, Universitas Ibn Khaldun Bogor \& Centre for Advanced Studies on Islam Science and Civilization Universiti Teknologi Malaysia, Pp. 34.

Al Faruqi, Ismail Raji' (1982) Islamization of Knowledge: General Principles and Workplan, Brentwood, Maryland: International Institute of Islamic Thought, Pp. 38-46.

Ali, M.D., Azhari, T, and Daud, H (1988), Islam untuk Disiplin Ilmu Hukum dan Sosial Politik: Buku Daras Pendidikan Agama Islam pada Perguruan Tinggi Umum, Jakarta: Bulan Bintang, Pp. 1-128.

Daud, Wan Mohd Nor Wan (1998), The Educational Philosophy and Practice of Syed Muhammad Naquib Al-Attas: An Explotion of the Original Concept of Islamization, Kuala Lumpur, Malaysia: International Institute of Islamic though and Civilization (ISTAC), Pp 291.

Drechsler, Wolfgang (2013) Islamic Public Administration - The Missing Dimension in NISPAcee (The Network of Institutes and Schools of Public Administration in Central and Eastern Europe) Research, NISPAcee Press, Pp.57-76.

(2013) "Three Paradgms of Governance and Administration: Chinese, Western and Islamic", Society and Economy, vol. 35, no.3, in press. 
(2014) What is Islamic Public Administration and why should we study it in the "Second World"?

(2015) "Islamic PA (Public Administration) - does it exist, what is it, and why and how should we study it?". Available at: http://dx.doi.org/10.1080/09540962.2015.966885, accessed on February 1, 2018.

Ebert IIES, Ebert C, Bentley ML, (2013). Curriculum. Available at: https://www.education.com/ reference/article/curriculum-definition/, accessed on January 9, 2018.

Handrianto, Budi, (2010) Islamisasi Sains: Sebuah Upaya Mengislamkan Sains Barat Modern, Jakarta: Al-Kautsar.

Hude, MD., Basri, H., Abbas, M., and Al-Hafizh, MA (2002) Cakrawala Ilmu dalam alQur'an, Jakarta: Penerbit Pustaka Firdaus, Bale Kajian Tafsir al-Qur'an Pase and Institut Perguruan Tinggi Ilmu al-Qur'an.

Husaini, Adian et.al (2013) Filsafat Ilmu, Jakarta: Gema Insani, Pp. 48.

Noer, Deliar (1978) Administration of Islam in Indonesia, Ithaca, New York: Cornel University, Pp. 8-65.

(1983) Administration of Islam in Indonesia (Administrasi Islam di Indonesia), Jakarta: Rajawali.

Noh, Abdillah (2014) "Islam Public Policy and Public Administration in Malaysia: Negotiating Complexities". Administrative Culture 15 (2) 204-221.

Qadri, Muhammad Ahmad (2016) "The Administration of Prophet Muhammad (PBUH) and Its Impact on the Contemporary States". Journal of Philosophy, Culture and Religion, Vol 17. Pp.30-34.

Rahim, Husni (1998) "Sistem Otoritas Administrasi Islam: Masa Kesultanan di Palembang", Jakarta: Logos Wacana Ilmu.

Rahman, Afzalur (1981), Quranic Science, Al-Qur'an Sumber Ilmu Pengetahuan (translate), Arifin, M. JakartaL PT Rineka Cipta, 2000.

Salleh, Mohammad Johdi and Mohamad, Nazifah Alwani (2012) "Islamic Principles of Administration: Implication on Pracies in Organization". Technology, Science, Social Sciences and Humanities International Conference - TeSSHI, Universiti Teknologi MARA Kedah One Helang Hotel, Lankawi, 14-15 November 2012.

Samier, Eugenie A (2014) "Designing Public Administration Curriculum for the United Arab Emirates: Principles for Graduate Programmes for a Modernising Arab Islamic State", Administrative Culture 15 (2) 222-246. 
Tafsir, Ahmad (2012) Ilmu Pendidikan Islami, Bandung: PT Remaja Rosdakarya. 
The Glossary of Education Reform (2015) Great Schools Partnership International License. Available at: https://www.edglossary.org/mission-and-vision/, acessed on February 14, 2018.

Undang-Undang Dasar Negara Republik Indonesia Tahun 1945.

Undang-Undang Republik Inonesia Nomor 20 Tahun 2003 tentang Sistem Pendidikan Nasional Universitas 'Aisyiyah Yogyakarta (n.d.), Vision and Mission. Availabel at https://www.unisayogya.ac.id, accesed on January 7, 2018.

Universitas Darussalam Ambon (n.d.), Vision and Mission. Available at www.unidarambon.ac.id, accessed on January 8, 2018.

Universitas Ibnu Chaldun Jakarta (n.d.), Vision and Mission. Available at: www.ibnuchaldun.ac.id, accessed on January 10, 2018.

Universitas Islam Jember (n.d.), Vision and Mission, http://fisipuij.blogspot.co.id/2016/07/visimisi-dan-tujuan-fakultas-ilmu.html, accessed on January 9, 2018.

Universitas Islam Kalimantan Banjarmasin (n.d.), Vision and Mission. Available at Uniskabjm.ac.id, accessed on January 8, 2018.

Universitas Islam Malang (n.d.), Vision and Mission. Available at: http://www.unisma.ac.id/statis-12-fakultas.html, accessed on January 8, 2018.

Universitas Islam Negeri ar-Raniry Banda Aceh (n.d.), Vision and Mission. Available at: http://www.ar-raniry.ac.id/visi-misi, accessed on January 8, 2018.

Universitas Islam Negeri Sultan Syarif Kasim Riau (n.d.) Vision and Mission. Available at: https://uin-suska.ac.id/profil/visi-dan-misi/, accessed on January 7, 2018.

Universitas Islam Negeri Sunan Gunung Jati Bandung, Vision and Mission. Available at: http://www.uinsgd.ac.id/front/arsip/page/kampus/visi-dan-misi, accessed on January 7, 2018.

Universitas Islam Riau (n.d.) Vision and Mission. Available at: Uir.ac.id, accessed on January 12, 2018.

Universitas Islam Syekh YusufTangerang (n.d) Vision and Mision. Available at: https://unis.ac.id, accessed on January 21, 2018.

Universitas Islam "45" Bekasi (n.d.) Vision and Mission. Available at: www.unismabekasi.ac.id/visi-dan-misi/, accessed on January 28, 2018.

Universitas Malikussaleh Lhokseumawe (n.d.) Vision and Mission. Available at: www.unimal.ac.id' accessed on January 6, 2018.

Universitas Mohammad Natsir Bukittinggi (n.d.) Vision and Mission. Available at: yarsisumbar.org, accessed on January 7, 2018. 
Universitas Muhammadiyah Jakarta (n.d.) Vision and Mission. Available at: Umj.ac.id. Universitas Muhammadiyah Makassar (n.d.)Vision and Mission. Available at: www.unismuh.ac.id, accessed on January 9, 2018.

Universitas Sultan Fatah Demak (n.d.) Vision and Mission. Available at: Unifat.ac.id, accessed on January 14, 2018.

Urinboyef, Rustamjon (2014) "Is there an Islamic Public Administration Legacy in Post-Soviet Central Asia? An Ethnograpic Study of Everyday Mahalla Life in Rural Ferghana, Uzbekistan", Administrative Culture 15 (2), 157-178.

Wiryanto, Wisber (2017) The Need of Public Administration: An Islamic Perspective for Higher Education in Indonesia, Proceeding International Conference on Administrative Science (ICAS) Paper Summary, Jurnal Analisis Kebijakan dan Pelayanan Publik (JAKPP) Department of Administrative Science, Universitas Hasanuddin, 20-21 November 2017, P.p.274-278. 